\title{
Kako pristupiti mjerenju seksualne orijentacije, spolnog i rodnog identiteta? Preporuke za istraživanja o temama koje se odnose na LGBTIQ osobe
}

DOI: $10.5613 /$ rzs.49.2.7

UDK: 303.1

303.2: $159.923 .2-055.3$

Pregledni rad

Primljeno: 19. 2. 2019.

\section{Marina MILKOVIĆ}

Centar za socijalnu skrb Zagreb, Podružnica Gornji grad - Medveščak, Zagreb, Hrvatska

marinamilkovic88@gmail.com

\section{Marina ŠTAMBUK}

Zavod za menadžment i ruralno poduzetništvo Agronomskog fakulteta Sveučilišta u Zagrebu, Hrvatska

mstambuk@agr.hr

\section{SAŽETAK}

Sve je više istraživanja u društvenim znanostima koja se bave temama povezanima s lezbijkama, gejevima, biseksualnim, transrodnim, interspolnim i queer (LGBTIQ) osobama u Hrvatskoj. Osim toga, u uzorku svakog istraživanja mogu biti i LGBTIQ osobe. Unatoč tomu, najčešće se pretpostavlja da su sve osobe u uzorku heteroseksualne i cisrodne, pa je u upitnicima koji mjere sociodemografske varijable često ograničen broj kategorija u kojima se LGBTIQ osobe mogu prepoznati. Posljedica takvog pristupa mjerenju nedovoljno je poznavanje ostvarenog uzorka, što može utjecati kako na tumačenje rezultata, tako i na odustajanje LGBTIQ osoba od sudjelovanja u istraživanju ili odgovaranja na pojedina pitanja. Takav pristup predstavlja i kršenje etičkog načela znanstvenog istraživanja o postupanju bez diskriminacije ili povlašćivanja na osnovi spola, rodnog identiteta i izražavanja ili seksualne orijentacije. Ovaj rad donosi preporuke za istraživanja u smjeru prepoznavanja LGBTIQ osoba, odnosno uključivanja različitih spolnih/rodnih identiteta i seksualnih orijentacija kao mogućnosti odgovora pri konstrukciji upitnika. Preporuke se temelje na pregledu različitih pristupa mjerenju spola, roda i seksualne orijentacije u hrvatskim i međunarodnim istraživanjima, teorijskim pretpostavkama te iskustvu autorica u stručnom radu s LGBTIQ osobama. Mogući korak prema prepoznavanju LGBTIQ identiteta jest uvođenje pitanja o seksualnoj orijentaciji i rodnom identitetu u istraživanja u kojima bi te varijable mogle biti relevantne za istraživanu temu. Također, s obzirom na to da se varijabla spola redovito koristi, uz uobičajene odgovore "muški" i "ženski", koji nisu primjenjivi na dio populacije, predlaže 
se ostavljanje prostora za samoidentifikaciju ili opciju "nešto drugo". Uz konkretne prijedloge čestica, rad donosi obrazloženja ključnih pojmova važnih za istraživanja koja uključuju LGBTIQ osobe.

Ključne riječi: seksualna orijentacija, spol, rod, identitet, mjerni instrument, LGBTIQ osobe

\section{UVOD}

Svrha je znanstvenog istraživanja na objektivan, točan i provjerljiv način mjeriti i opisati predmet proučavanja. To je tako jer, između ostaloga, o rezultatima znanstvenih istraživanja ovisi ljudska percepcija stvarnosti. Dakle, pogrešno mjerenje može dati iskrivljenu sliku o predmetu istraživanja, ali i na pogrešan način oblikovati odnos društva prema tom predmetu istraživanja. Također, o odluci što sve mjeriti ovisi i vidljivost određene pojave u društvu. Kad je riječ o LGBTIQ osobama (lezbijkama, gejevima, biseksualnim, transrodnim, ${ }^{1}$ interspolnim ${ }^{2}$ i queer), taj se problem očituje kroz njihovu nevidljivost u znanstvenim istraživanjima koja nemaju primaran cilj istraživati teme usko vezane za tu populaciju. Ako pretpostavljamo da su sve osobe koje sudjeluju u istraživanju heteroseksualne orijentacije i da je jedino moguće da budu muškog ili ženskog spola, koji k tome poistovjećujemo s rodom, izostavljamo i činimo neprepoznatim cijeli jedan dio populacije. Stoga je važno aktivno promišljati kako učiniti istraživanja uključivim za LGBTIQ osobe čak i kad teme vezane uz LGBTIQ osobe nisu glavni fokus istraživanja.

Osim u istraživanjima koja se odnose na LGBTIQ osobe, seksualna orijentacija postaje čestom sociodemografskom varijablom u međunarodnim istraživanjima na nacionalno reprezentativnim uzorcima, što omogućuje procjenu brojnosti LGBTIQ osoba u općoj populaciji te ispitivanje specifičnosti nekih općih društvenih pitanja kod LGBTIQ osoba (Gates, 2011). Dakle, važno je sagledati teorijsku podlogu i operacionalizaciju te varijable u istraživanjima i zatim različite mogućnosti mjerenja i njihove implikacije na prikupljene podatke. Osim toga, sve je jasnije da i mjerenju drugih sociodemografskih pokazatelja treba pristupiti kritički propitujući što zapravo mjerimo (konstruktnu valjanost mjere) i koliko uspješno razlikujemo sudionike/ ce (osjetljivost mjere). Na primjeru mjerenja spola možemo vidjeti kako mnogi istraživači/ce rutinski koriste jednu česticu nudeći samo dvije opcije, muški i ženski, te u internetskim anketama uvjetuju odgovor na to pitanje za nastavak sudjelovanja u istraživanju. Pritom ne propituju učinak odabira takvog pristupa mjerenju na dobi-

1 Transrodne osobe su one čiji se rodni identitet razlikuje od rodnog identiteta očekivanoga za spol koji im je pripisan pri rođenju.

2 Interspolna osoba je osoba rođena sa spolnim karakteristikama koje se ne uklapaju u medicinske i društvene norme ženskih ili muških spolnih karakteristika. 
vene rezultate. $U$ istraživanjima na velikim nacionalno reprezentativnim uzorcima ta jedna čestica s dva ponuđena odgovora nudi pristran opis populacije, a njezino korištenje $\mathrm{u}$ istraživanjima s LGBTIQ osobama predstavljalo bi značajan metodološki nedostatak.

Dakle, kako bi se ostvarili ciljevi istraživanja na empirijski valjanim i psihometrijski utemeljenim rezultatima, točan opis karakteristika sudionika/ca trebao bi biti ispred potrebe za pojednostavljivanjem stvarnosti. U tom smislu, svrha je ovog rada ukazati istraživačima/cama na potrebu za upoznavanjem i razumijevanjem specifičnosti LGBTIQ osoba i dati preporuke za unapređenje anketnih istraživanja u području mjerenja seksualne orijentacije te spolnog i rodnog identiteta, i to ne samo među LGBTIQ populacijom, nego i u istraživanjima na općoj populaciji.

\section{KOJA SE TO ISTRAŽIVANJA ODNOSE NA LGBTIQ OSOBE?}

Eksplicitno uključivanje LGBTIQ osoba u istraživanja često je rezervirano samo za istraživanja koja su namijenjena toj skupini te isključuju osobe heteroseksualne orijentacije i cisrodne ${ }^{3}$ osobe. Istodobno, istraživanja opće populacije obično su namijenjena osobama heteroseksualne orijentacije i cisrodnim osobama te isključuju LGBTIQ osobe.

U Hrvatskoj nema istraživanja koja bi procjenjivala broj LGBTIQ osoba u populaciji. Dosad se u popisima stanovništva nisu bilježili podaci o seksualnoj orijentaciji i rodu, a spol je mjeren dvjema opcijama (muški i ženski). U posljednjem popisu stanovništva (Državni zavod za statistiku, 2011b) zabilježeno je da 140 ljudi živi u istospolnim zajednicama te je Ministarstvo uprave (2016, 2017, 2018, 2019a, 2019b) zabilježilo 297 sklopljenih životnih partnerstava osoba istog spola od 2014. godine do svibnja 2019. Dakle, dostupni podaci govore samo o zajednicama osoba istog spola i ne omogućavaju zaključivanje o brojnosti LGBTIQ populacije u Hrvatskoj.

U međunarodnim istraživanjima postoje preciznije procjene o zastupljenosti LGBT osoba u populaciji. Primjerice, rezultati Gallupovog istraživanja (Newport, 2018) pokazali su da se $4,5 \%$ odraslih osoba u Sjedinjenim Američkim Državama (SAD) identificira kao lezbijke, gejevi, biseksualne ili transrodne osobe. To bi značilo da u SAD-u živi otprilike 11 milijuna LGBT osoba. Procjena raširenosti LGBTIQ osoba u nekom društvu podrazumijeva više izazova i može varirati ovisno o korištenoj metodologiji i česticama u upitniku (Gates, 2011). ${ }^{4}$

Cisrodne osobe su one čiji se rodni identitet podudara sa spolom koji im je pripisan rođenjem.

$4 \quad$ Vidjeti cjelinu “Kako postaviti pitanja o seksualnim i rodnim identitetima?" u nastavku teksta. 
Poteškoće su prisutne i pri procjeni raširenosti transrodnih, transpolnih ${ }^{5}$ i rodno nenormativnih osoba. ${ }^{6} \mathrm{U}$ istraživanja se često uključuju samo transpolne osobe koje su zatražile neki oblik zdravstvene skrbi jer in je najlakše identificirati (Svjetska strukovna organizacija za zdravlje transrodnih osoba, 2012). Vrijednosti raširenosti transpolnih osoba kreću se od 1:11 900 do 1:45 000 za MtF i 1:30 400 do 1:200 000 za FtM osobe. ${ }^{7}$ Te brojke treba shvatiti kao minimalne procjene jer su isključene osobe čiji se rodni identitet ne poklapa sa spolom pripisanim po rođenju, a koje nemaju potrebu za medicinskim intervencijama. Broj interspolnih osoba u populaciji također je teško utvrditi. Američka psihološka asocijacija (2006) navodi procjenu da se 1 na 1500 novorođenčadi rađa s vanjskim spolnim obilježjima koja se ne mogu jasno klasificirati u muška ili ženska, a pritom vanjska spolna obilježja nisu jedini pokazatelj interspolnosti. To mogu biti i nepotpun ili neuobičajen razvoj unutarnjih reproduktivnih organa, nekonzistentnost između vanjskih i unutarnjih organa, abnormalnosti spolnih kromosoma ili razvoja spolnih žlijezda, pretjerana ili premala proizvodnja spolnih hormona ili nesposobnost tijela da na uobičajen način odgovara na spolne hormone.

Unatoč nepostojanju točnih procjena, znamo da LGBTIQ osobe postoje u Hrvatskoj, stoga treba imati na umu da u većini istraživanja mogu biti dio uzorka i u skladu s tim ne treba pretpostavljati heteroseksualnost i cisrodnost svih sudionika/ ca istraživanja. Također, upravo zbog nepostojanja podataka o brojnosti LGBTIQ osoba, bilo bi korisno u sljedeći popis stanovništva, kao i u istraživanja na velikim nacionalno reprezentativnim uzorcima, uvrstiti pitanja o seksualnoj orijentaciji te spolnom i rodnom identitetu.

lako se LGBTIQ osobe mogu naći u uzorku bilo kojeg istraživanja, informacija o seksualnoj orijentaciji ili rodnom identitetu ne mora biti relevantna za svako istraživanje. Stoga je pri sastavljanju upitnika važno procijeniti je li u pitanja o sociodemografskim karakteristikama sudionika/ca potrebno uvrstiti i pitanja o seksualnoj orijentaciji i rodnom identitetu. Na primjer, u istraživanjima koja ispituju partnerske odnose trebalo bi ili specificirati da se istraživanje odnosi isključivo na heteroseksualne odnose ili postaviti pitanje o seksualnoj orijentaciji sudionika/ca, umjesto automatskog pretpostavljanja njihove heteroseksualnosti. U istraživanjima se često postavlja pitanje bračnog statusa te bi u tom slučaju bilo ispravno u ponu-

5 Transpolne osobe su one koje žele prilagoditi ili su već prilagodile svoje primarne i/ili sekundarne spolne karakteristike vlastitom rodnom identitetu s pomoću medicinskih intervencija.

6 Rodno nenormativno pridjev je kojim se opisuju osobe čiji se rodni identitet, rodna uloga ili rodno izražavanje razlikuju od onoga što je u određenoj kulturi i povijesnom razdoblju normativno za spol koji im je pripisan (Svjetska strukovna organizacija za zdravlje transrodnih osoba, 2012).

7 MtF (male-to-female) i FtM (female-to-male) jesu osobe čiji se smjer tranzicije kreće od obrazaca muškosti prema obrascima ženskosti, odnosno ženskosti prema muškosti. 
đenim odgovorima navesti sve postojeće zakonske mogućnosti registriranja neke partnerske zajednice, odnosno opciju životnog partnerstva osoba istog spola, ili istaknuti da se istraživanje odnosi samo na heteroseksualne osobe.

Uobičajena sociodemografska varijabla je i spol. Pritom se $u$ istraživanjima redovito nude samo dvije opcije - "muški" i "ženski". S pozicije sagledavanja konstruktne valjanosti i metrijske osjetjivosti takve mjere, opravdano je postaviti pitanje koji bi odgovor trebala izabrati interspolna ili transpolna osoba. Jedno od temeljnih etičkih načela u znanosti, sukladno članku 8. Etičkog kodeksa Hrvatske zaklade za znanost (2018), jest poštovanje integriteta i dostojanstva, što podrazumijeva i postupanje bez diskriminacije ili povlašćivanja na osnovi spola, rodnog identiteta, izražavanja ili spolne orijentacije. Ako u provedbi istraživanja zanemarujemo činjenicu da se sve osobe ne mogu svrstati u kategorije muškog ili ženskog spola, stavljamo te osobe u nepovoljan položaj u odnosu na druge sudionike/ce i kršimo to etičko načelo.

Kod mjerenja različitih karakteristika manjinskih skupina u društvu važno je spomenuti i temu provođenja statističkih analiza ovisno o veličini poduzoraka. U znanstvenim istraživanjima, preduvjet za provedbu analiza na skupinama koje se razlikuju s obzirom na neku relevantnu varijablu jest veličina tih skupina. Za očekivati je da broj osoba koje će izabrati "nešto drugo" kod pitanja o spolu biti višestruko manji od onih koji će odabrati opciju "muško" ili "žensko". U tom slučaju, istraživači/ce mogu donijeti odluku na koji će način pristupiti analizama i ovisno o cilju istraživanja mogu se odlučiti za provođenje analiza na cijelom uzorku ili isključivanje jednog dijela uzorka uz teorijski i metrijski primjerenu argumentaciju. Za usporedbu, u Hrvatskoj prema posljednjem popisu stanovništva iz 2011. (Državni zavod za statistiku, 2011a) postoje 22 nacionalne manjine. Ako u istraživanju koristimo varijablu nacionalnosti, vjerojatno će nam biti važno da se u tom istraživanju svaka osoba može izjasniti o svojoj nacionalnosti, bez obzira na to što nekih pripadnika nacionalnih manjina ima više (npr. Srba $-4,36 \%$ stanovništva), a nekih manje (npr. Rumunja - 0,01\% stanovništva). U takvom istraživanju metrijski neopravdano bi bilo uvjetovati odgovor na pitanje o nacionalnosti u kojem su kao odgovori ponuđene samo nekoliko brojnijih nacionalnih manjina bez mogućnosti otvorenog odgovora za samoidentifikaciju ili opcije "nešto drugo". Pritom varijablu nacionalnosti, kao ni varijablu seksualne orijentacije, nećemo koristiti u svakom istraživanju, kao što je to uobičajeno za varijablu spola, zbog čega odluke o načinu mjerenja spola imaju učinke na veći broj istraživanja. 


\section{KOJE JE POJMOVE VAŽNO RAZUMJETI?}

Prilikom provedbe istraživanja koja uključuju LGBTIQ osobe potrebno je poznavati i razumjeti osnovne pojmove poput seksualne orijentacije, spolnog/rodnog identiteta i rodnog izražavanja. U međunarodnoj znanstvenoj literaturi postoji zamjetan opus radova koji se bave problematikom mjerenja spola, roda i seksualne orijentacije te implikacijama odabira različitih pristupa u mjerenju na dobivene rezultate (npr. Sell, 2007; Westbrook i Saperstein, 2015). Također, unutar znanstvene zajednice postoji nekoliko inicijativa koje donose konkretne preporuke za mjerenje i istraživanje tih pojmova (npr. Sexual Minority Assessment Research Team, 2009; Federal Interagency Working Group on Improving Measurement of Sexual Orientation and Gender Identity in Federal Surveys, 2016a, 2016b).

Na području Hrvatske pojmovi vezani uz seksualnu orijentaciju, spolni i rodni identitet objašnjavani su najčešće u literaturi udruga koje se bave pravima LGBTIQ osoba i obrađivani unutar nastave na, najčešće izbornim, kolegijima visokoškolskih ustanova. Stječe se dojam da u široj znanstvenoj zajednici postoji nezainteresiranost za pravilno mjerenje te zbunjenost oko značenja različitih termina i načina njihova korištenja izvan područja istraživanja koja se izravno bave LGBTIQ osobama ili odnosom prema LGBTIQ osobama (npr. Štulhofer, 2004; Huić, Jelić i Kamenov, 2015). Usto, mjere seksualne orijentacije te spolnog i rodnog identiteta ne uključuju se $u$ istraživanja na općoj populaciji.

Mogući je razlog izbjegavanja tih mjera $u$ istraživanjima na općoj populaciji i strah da će u heteronormativnom društvu kao što je suvremeno hrvatsko (European Union Agency for Fundamental Rights, 2014) uključivanje tih mjera utjecati na sudjelovanje $u$ istraživanju. U Hrvatskoj nije empirijski provjereno bi li uvođenje novih kategorija i pitanja vezanih uz spolni/rodni identitet i seksualnu orijentaciju utjecalo na spremnost sudionika/ca na sudjelovanje u istraživanju ili davanje odgovora na ta pitanja. Međutim, rezultati međunarodnih istraživanja, uglavnom u sjevernoameričkom kontekstu, pokazuju da sudionici/e takva pitanja ne doživljavaju prijetećim i spremno daju odgovore na njih (Case i dr., 2006; Schilt i Bratter, 2015). Empirijski potkrijepljeni odgovori na ta pitanja dobiveni u hrvatskom kontekstu bili bi značajan doprinos ovom području te bi dali jasnije smjernice za buduća istraživanja.

\subsection{Seksualna orijentacija}

Seksualna orijentacija može se definirati kao trajni obrazac emotivne, romantične i seksualne privlačnosti prema osobama istoga, različitog ili oba spola/roda. Uključuje osjećaj vlastitog identiteta temeljenog na toj privlačnosti i povezana pona- 
šanja te osjećaj pripadnosti zajednici osoba iste seksualne orijentacije (Američka psihološka asocijacija, 2008). Raznolikost samoodređenja s obzirom na seksualnu orijentaciju često je veća od nekoliko kategorija te se seksualna orijentacija može definirati i u obliku kontinuuma između privlačnosti prema osobama istoga odnosno različitog spola/roda. Također, neke osobe svoju seksualnu orijentaciju definiraju izvan binarnih kategorija muškosti odnosno ženskosti, kao na primjer panseksualne osobe, koje osjećaju privlačnost prema drugim osobama neovisno o spolu/rodu tih osoba (Američka psihološka asocijacija, 2015b).

Seksualna orijentacija podrazumijeva nekoliko dimenzija - seksualni identitet, seksualnu privlačnost i seksualno ponašanje (Moser, 2016). Seksualni identitet odnosi se na to kako se osoba identificira u odnosu na vlastitu seksualnost. Seksualni identiteti mogu biti lezbijka, gej muškarac, biseksualna osoba, aseksualna osoba ${ }^{8}$ i drugi. Osobe heteroseksualne orijentacije dio su većinske skupine stoga, kao i pripadnici/e drugih većinskih skupina, tu svoju karakteristiku rijetko doživljavaju u terminima identiteta (Simoni i Walters, 2001). Seksualna privlačnost odnosi se na to koje osobe mogu seksualno privući neku osobu, neovisno o tome ulazi li osoba u odnose s njima ili ne. Tako neke ljude privlače samo muškarci, neke samo žene, a neke oboje. Seksualno ponašanje odnosi se na načine izražavanja vlastite seksualnosti, odnosno na to s kim osoba stupa u seksualne odnose. Opisani pojmovi mogu se, ali i ne moraju, poklapati. Na primjer, osoba koja se identificira kao lezbijka i privlače ju žene može imati i iskustvo seksualnih odnosa s muškarcima, ili osoba biseksualne orijentacije koju privlače i muškarci i žene, može imati samo iskustvo seksualnog odnosa s osobama različitog spola.

\subsection{Spolni i rodni identitet}

U novije vrijeme na području društvenih znanosti prevladava slaganje o odnosu spola i roda u nekoliko ključnih točaka (Westbrook i Saperstein, 2015). lako su povezani, spol i rod predstavljaju različite konstrukte, a načini na koji se osobe samoidentificiraju u terminima spola i/ili roda ne moraju odgovarati onomu kako ih drugi vide.

Pri istraživanju spolnog i rodnog identiteta potrebno je razlikovati nekoliko ključnih pojmova - spol, rod, spolni identitet, rodni identitet i rodno izražavanje. Spol je društvena kategorija temeljena na biološkim karakteristikama te s obzirom na spol osoba može biti muškog spola, ženskog spola ili može biti interspolna (Američka psihološka asocijacija, 2015b). Spol se definira s pomoću više bioloških karakteristika kao što su spolni kromosomi, spolni hormoni, spolne žlijezde te unutarnji i

\footnotetext{
8 Aseksualne osobe druge osobe seksualno ne privlače.
} 
vanjski spolni organi. S druge strane, rod podrazumijeva društvena očekivanja i norme oko specifičnih stavova, osjećaja i ponašanja koji se vežu uz muževnost odnosno ženstvenost. Individualni doživljaj vlastitog spola predstavlja spolni identitet, a individualni doživljaj vlastitog roda predstavlja rodni identitet osobe (Tate, Ledbetter i Youssef, 2013). S obzirom na spol, osobe se mogu identificirati kao osobe muškog spola, ženskog spola, interspolne, transpolne ili se mogu odbiti identificirati s obzirom na spol. S obzirom na rod osobe se mogu identificirati kao žene, muškarci, transrodne osobe, mogu se odbiti identificirati s obzirom na rod ili se identificirati s različitim nebinarnim identitetima (npr. genderqueer ${ }^{9}$ ). Rodno izražavanje je način na koji osoba izražava svoj rodni identitet (kroz odijevanje, frizuru, govor tijela i drugo).

U pogledu spola, ljude se većinom odmah po rođenju svrstava u osobe muškog ili ženskog spola, što isključuje interspolne osobe (European Union Agency for Fundamental Rights, 2015). Također, u velikom broju europskih zemalja provode se medicinske intervencije "normalizacije" spola, često bez mogućnosti da dijete o tome samo donese odluku. Takve medicinske intervencije provode se i u Hrvatskoj (Batinica, 2010). Ipak, posljednjih godina neke europske države prepoznaju taj problem te omogućuju klasificiranje spola po rođenju izvan binarnih kategorija "muškog" i "ženskog” (European Union Agency for Fundamental Rights, 2015). Osim u svrhu identificiranja interspolne novorođenčadi, alternativne oznake spola izvan binarnih kategorija muškog i ženskog uvode se i za potrebe transrodnih, transpolnih i rodno nenormativnih osoba u sve više zemalja, od kojih su neke Malta, Danska, Kanada i Australija u kojima postoji opcija oznake spola "X" (Transgender Europe, 2017).

Tako prikazana raznolikost spolnih/rodnih identiteta najbolje prikazuje problematičnost traženja odgovora samo na varijablu spola s dvije kategorije odgovora - muški i ženski. Westbrook i Saperstein (2015) naglašavaju kako se kontinuiranim nuđenjem samo tih dviju kategorija šalje implicitna poruka kako ništa drugo osim te dvije kategorije ne postoji. To ugrožava konstruktnu valjanost i osjetljivost korištenih mjera te ne odražava stvarnu raznolikost istraživanog obilježja u populaciji. Isti autori ukazuju i na tendenciju podrazumijevanja nepromjenjivosti spola/roda osobe tijekom života u longitudinalnim istraživanjima. Naime, čak i u dugotrajnim longitudinalnim istraživanjima spol i rod se najčešće mjere samo u prvom valu istraživanja.

Osim spomenutoga, treba primijetiti kako se i u engleskom govornom području, ali i u znanstvenim tekstovima na hrvatskom jeziku, često termini "spol" i "rod"

9 Genderqeer je rodni identitet koji ne ovisi o binarnim kategorijama muškosti/ženskosti (Factor i Rothblum, 2008). 
koriste kao sinonimi bez jasnog obrazloženja ili utemeljenosti u mjeri koja je primijenjena. Na Portalu hrvatskih znanstvenih i stručnih časopisa (Hrčak) pretragom "spolnih razlika" dolazi se do 64 rada, a pretragom "rodnih razlika" do 172 rada. Kad je riječ o empirijskim radovima, opis mjerenja varijable na kojoj se temelje testovi razlika najčešće nije opisan u metodi, nego se kod prikaza rezultata uspoređuju dvije kategorije, "muška" i "ženska" (npr. dječaci i djevojčice, mladići i djevojke, učenici i učenice). Također, uobičajeno je da se u istraživanju spol mjeri dvjema kategorijama (muški i ženski), dok se u raspravi govori o rodnim razlikama. Samo se u istraživanjima s LGBTIQ populacijom mogu pronaći opisi mjerenja te istodobno mjerenje spolnog i rodnog identiteta (npr. Kamenov, Jelić i Huić, 2016).

Iz pozicije psihologije postoji niz dokumenta s preporukama o radu s osobama nenormativnih spolnih i rodnih identiteta koje smatramo da je važno poštovati i u istraživačkom radu, kako u psihologiji, tako i unutar drugih znanosti. Jedno od temeljnih načela Kodeksa etike psihološke djelatnosti (Hrvatska psihološka komora, 2004) uvažavanje je ljudskih prava i dostojanstva. U članku 2. stoji da će psiholozi i psihologinje u svom radu izražavati bespogovorno poštovanje temeljnih ljudskih prava, dostojanstva i vrijednosti svih ljudi, da će kod svakog pojedinca/ke s kojim dolazi u profesionalni doticaj poticati razvoj tih vrijednosti uvažavajući pravo pojedinca/ke na privatnost i tajne, kao i pravo na samoodređenje, te da će u svom radu nastojati otkloniti sve oblike diskriminacije. $U$ dijelu koji se odnosi na znanstvenu odgovornost (članak 25., stavak 1.) stoji da bi psiholozi i psihologinje trebali provoditi istraživanja kompetentno vodeći brigu o dostojanstvu i dobrobiti sudionika/ca.

U međunarodnom kontekstu, Američka psihološka asocijacija (2015a) donijela je slične smjernice za rad s transrodnim i rodno nenormativnim osobama. Prema tim smjernicama, psiholozi i psihologinje bi u svom radu trebali imati na umu da je rod nebinaran konstrukt i da se ne mora podudarati sa spolom koji je osobi pripisan po rođenju te da su rodni identitet i seksualna orijentacija različiti, iako povezani, konstrukti. Također, psiholozi i psihologinje bi trebali poštovati dobrobit i prava transrodnih i rodno nenormativnih osoba koje sudjeluju u istraživanjima te težiti točnom prikazivanju dobivenih rezultata i izbjegavati njihovu zlouporabu.

Temeljem spomenutoga može se zaključiti da bi suvremena istraživanja trebala prepoznavati spol i rod kao odvojene konstrukte te uzimati u obzir da se ne mogu sve osobe svrstati u binarne kategorije muškog i ženskoga, kako roda, tako ni spola. U pravnom smislu sve se češće uvode opcije prikladnije za transrodne, transpolne, rodno nenormativne i interspolne osobe te u skladu s tim postoji potreba revidiranja uobičajenih mjera u istraživanjima koje su još uvijek uglavnom svedene na mjerenja spola samo dvjema opcijama. 


\subsection{Queer}

Dosad su kroz tekst spomenuti svi identiteti iz akronima LGBTIQ, osim posljednjega. Queer je pojam koji zapravo ne označava identitet, nego odnos prema društvenim normama u smislu odbacivanja tih normi, napose onih vezanih za seksualnu orijentaciju, spolni/rodni identitet i rodno izražavanje. Termin je prvi put upotrijebila feministička teoretičarka Teresa de Lauretis 1991. s ciljem kritičkog propitivanja gej/lezbijskih identiteta i tri godine kasnije ga se javno odrekla, ali se termin nastavio koristiti (Durkalić, 2012). Među LGBTIQ osobama postoje osobe koje se identificiraju kao queer te se u istraživanjima taj pojam pojavljuje kao jedan od mogućih identiteta (npr. Factor i Rothblum, 2008).

Dakle, pojam queer ima višestruko značenje. Predstavlja i identitet, i teoriju o nenormativnoj heteroseksualnosti, ali i teorijski pristup koji se bavi razumijevanjem pojma identiteta. $S$ jedne strane, queer se suprotstavlja esencijalističkom pogledu na rodne uloge, rodni identitet i seksualnu orijentaciju te na njih gleda kao na društvene konstrukte. S druge strane, u smislu identiteta, možda je najbolje opisan definicijom identiteta bez esencije (Halperin, 1995, prema Nagoshi, Nagoshi i Bruzuzy, 2014).

\subsection{Odnos seksualne orijentacije, spolnog i rodnog identiteta}

Važno je razumjeti da nema pravila oko preklapanja opisanih pojmova. Seksualna orijentacija ne ovisi o spolnom/rodnom identitetu i obratno. Osobe različitih seksualnih orijentacija mogu se razlikovati s obzirom na spolni/rodni identitet u svim smjerovima i obratno. Na primjer, lezbijke mogu biti i cisrodne žene i transrodne žene, a transrodni muškarac može biti homoseksualne, heteroseksualne, biseksualne, panseksualne ili bilo koje druge seksualne orijentacije.

Spomenuto se potvrđuje i u istraživanjima koja su ispitivala spolni i rodni identitet te seksualnu orijentaciju. Prema rezultatima, seksualne orijentacije transrodnih $\mathrm{i}$ transpolnih osoba razlikuju se i ne mogu se pretpostaviti temeljem njihova spolnog niti rodnog identiteta te su u uzorcima različito zastupljene heteroseksualna, homoseksualna i biseksualna orijentacija, kao i identificiranje izvan okvira tih uobičajenih kategorija seksualne orijentacije (npr. kao queer, Maragh-Bass i dr., 2017; lantaffi i Bockting, 2011). 


\section{KOJU BI TERMINOLOGIJU VEZANU UZ LGBTIQ OSOBE TREBALO POZNAVATI?}

Prije provedbe istraživanja koje uključuje LGBTIQ osobe treba poznavati primjerene termine te ih razlikovati od pogrdnih i zastarjelih. Sukladno tomu, preporučuje se govoriti o seksualnoj orijentaciji, a ne o preferenciji, jer potonje sugerira da je riječ o izboru osobe da je privlače osobe određenog spola, što je netočno (Američka psihološka asocijacija, 1991). Nadalje, prikladnije je govoriti o osobama homoseksualne, heteroseksualne ili biseksualne orijentacije umjesto o homoseksualcima, heteroseksualcima i biseksualcima ili o homoseksualnim, heteroseksualnim i biseksualnim osobama. Naime, pridjev (homoseksualna osoba) i imenica (homoseksualac) sugeriraju da je seksualna orijentacija jedino obilježje te osobe i osobu svodi samo na to obilježje. Slične promjene uvriježene terminologije za neku skupinu osoba već su se događale u stručnom i zdravstvenom diskursu. Kad govorimo o problemima mentalnog zdravlja, neprikladno je govoriti u obliku pridjeva (npr. psihički bolesna osoba, depresivna osoba) i rabimo drukčije termine (npr. osoba s teškoćama mentalnog zdravlja, osoba koja pati od depresije). Također, seksualna orijentacija ne podrazumijeva samo seksualnu privlačnost, nego i romantičnu i emotivnu, pa se tako pojmovima poput gej i lezbijka izbjegava naglašavanje i svođenje identiteta osobe samo na seksualnu komponentu. Osim toga, termini "homoseksualac" i "homoseksualizam" u prošlosti su se vezali uz devijantno ponašanje, psihičke bolesti i kriminalno ponašanje te se korištenjem tih termina mogu perpetuirati stereotipi o osobama neheteroseksualnih orijentacija (Sell, 2007). Još jedan razlog za izbjegavanje termina "homoseksualac" jest i to što se često veže samo uz muškarce, a lezbijski identitet čini manje vidljivim.

Kad govorimo o različitim spolnim/rodnim identitetima, pravilni su termini transrodne osobe (eng. transgender), transpolne osobe (eng. transsexual) ili skraćeno transosobe. Termini poput transseksualci ili transseksualnost zapravo su pogrešno prevedeni s engleskog jezika, u kojem se za spol i seksualni čin rabi ista riječ. U skladu sa spomenutim, interspolnost (eng. intersex) pravilan je termin u odnosu na interseksualnost. Dakle, transpolnost i interspolnost nisu povezane sa seksualnošću, nego sa spolom. Također, kad govorimo o medicinskim intervencijama kod transpolnih osoba, primjereno je koristiti "prilagodba spola" umjesto "promjena spola". Termin "prilagodba spola" sukladniji je uvriježenom izrazu u engleskom jeziku (sex reassignment) i točniji za opis samog procesa jer osoba svoje spolne karakteristike prilagođuje vlastitom identitetu u onoj mjeri u kojoj joj je to potrebno. ${ }^{10}$

Treba istaknuti i to da je spomenuta terminologija sadržana u Standardima skrbi za zdravlje transrodnih, transpolnih i rodno nenormativnih osoba (Svjetska strukov-

10 Za više informacija o stupnjevitosti prilagodbe spola vidjeti u Svjetska strukovna organizacija za zdravlje transrodnih osoba (2012). 
na organizacija za zdravlje transrodnih osoba, 2012) kao i u drugim relevantnim dokumentima koji daju stručne smjernice za rad s transrodnim, transpolnim i rodno nenormativnim osobama (npr. Američka psihološka asocijacija, 2015a). U Hrvatskoj, prema Kodeksu etike psihološke djelatnosti (članak 25., stavak 4.), dužnost je psihologa i psihologinje, pri istraživanju specijalnih populacija, savjetovati se sa stručnjacima i stručnjakinjama za tu populaciju. To je nužno i u slučaju transrodnih, transpolnih i interspolnih osoba kako bi se izbjegla povreda njihova dostojanstva i dobrobiti. Vodeći se smjernicama Kodeksa, korištenje pogrešnih termina ukazuje na neznanje, nerazumijevanje, a time i nepoštovanje osoba tih identiteta.

U svakodnevnom govoru uobičajeno je i korištenje sintagme "suprotan spol" koja potkrepljuje polarizaciju između muškaraca i žena te sugerira kako zaista postoje suprotnosti među njima, iako je zapravo riječ o razlikama. Zbog takvih konotacija treba izbjegavati znanstveno komentiranje razlika u terminima suprotnosti, ne samo kad je riječ o osobama različitog spola/roda, nego i o osobama različitih seksualnih orijentacija.

Primjerena i precizna terminologija važna je i prilikom opisivanja partnerskih odnosa i obitelji LGBTIQ osoba, a ovisi o identitetima o kojima govorimo. Na primjer, "lezbijski par" ili "gej par" dobar je termin u slučaju kad se obje osobe u paru identificiraju kao lezbijke odnosno gejevi. Ipak, u slučaju da su jedna ili obje osobe $\mathrm{u}$ paru biseksualne orijentacije, ti termini ne bi bili primjereni jer se na taj način identitet osobe određuje temeljem njezinoga trenutnog partnerskog odnosa, što je pogrešno. U tom bi slučaju bolje bilo govoriti o vezi osoba istog spola. Taj termin istodobno može biti neprimjeren za transrodne osobe, odnosno, na primjer, za vezu transrodne žene koja se identificira kao lezbijka i cisrodne žene. Kad se govori o obiteljima LGBTIQ osoba povremeno se pojavljuju termini poput "istospolne obitelji" ili "homoseksualne obitelji", što je pogrešno jer parovi mogu biti istog spola ili homoseksualne orijentacije, ali ne znači da je to slučaj sa svim članovima/cama obitelji. Bolji izbor termina bio bi LGBTIQ obitelji, obitelji s LGBTIQ roditeljima, ili u neformalnom kontekstu često korišten pojam "dugine obitelji”.

\section{ZAŠTO JE VAŽNO POSTAVITI PRAVO PITANJE?}

Temeljit opis mjerenja sociodemografskih varijabli često se izostavlja u opisu instrumentarija i te se mjere generički primjenjuju iz istraživanja u istraživanje. Ipak, kao i kod primjene ostalih mjera u društvenim istraživanjima, odluka o načinu mjerenja takvih varijabli podrazumijeva mnoštvo različitih odluka. Konačne odluke o tome hoćemo li pitanje postaviti u otvorenom ili zatvorenom obliku, kako ćemo nazvati ponuđene opcije i hoće li opcije biti međusobno isključive te koliko ćemo opcija ponuditi i hoćemo li ponuditi opciju "ne znam" mogu imati značajne efekte na 
odgovore koje ćemo prikupiti, na formiranje rezultata te na usmjeravanje obrade i interpretaciju rezultata (Schaeffer i Dykema, 2011).

$\mathrm{Na}$ tom području važna je tema vaganja prednosti i nedostataka otvorenih i zatvorenih pitanja. S jedne strane, zatvorena pitanja sužavaju odgovore sudioni$\mathrm{ka} / \mathrm{ca}$, dok s druge strane otvorena pitanja omogućuju sudionicima/cama davanje odgovora neovisnog o utjecaju istraživača/ica. Kao prednosti otvorenih pitanja najčešće se spominje mogućnost dobivanja opsežnijih i spontanijih odgovora za koje je veća vjerojatnost da doista pokrivaju cijeli spektar obilježja sudionika/ica. Ipak, takva pitanja imaju i nedostatke kao što su dulje vrijeme potrebno za obradu podataka i veći postotak izbjegavanja odgovora na pitanja (Reja i dr., 2003; Schaeffer i Dykema, 2011). U skladu s navedenim uvriježen je pristup korištenja otvorenih pitanja u prvim fazama istraživanja (npr. pilt-istraživanje) kako bi se na temelju prikupljenih podataka formirale opcije odgovora za zatvorena pitanja (Milas, 2009). Kad raspravljamo o razlikama između otvorenih i zatvorenih pitanja treba imati na umu i razliku između otvorenih pitanja u kojima se traži mišljenje sudionika/ca (npr. "Što je, po vama, najveći problem s kojim se susreću LGBTIQ osobe?"), kad rezultati mogu biti pristrani zbog salijentnosti određenih tema u danom trenutku, i tzv. "identifikacijskih pitanja", u kojima se traži specifična informacija (npr. frekventnost nekog ponašanja ili mjesečna primanja) kod kojih je veći problem izbjegavanje davanja odgovora (Dohrenwend, 1965, prema Schaeffer i Dykema 2011). Jedan od načina ublažavanja nedostataka zatvorenih pitanja bilo bi dodavanje opcije odgovora "nešto drugo", koja može biti popraćena prostorom za dopisivanje odgovora (Reja i dr., 2003). Na taj način daje se prostor sudionicima/ama za samoidentifikaciju ako se ne mogu pronaći u ponuđenim odgovorima, a prevenira se rizik izbjegavanja odgovora i zahtjevnije analize podataka.

Neki autori/ice smatraju kako je važno zadržati iste mjere zbog osiguravanja usporedivosti rezultata čak i kad znamo da korištene mjere nisu optimalne za mjerenje pojave koju želimo obuhvatiti (Krosnick i Presser, 2010). Ipak, teorijska podloga konstrukata spolnog i rodnog identiteta u značajnom je nerazmjeru s uobičajenim načinima mjerenja, pa bi za te varijable primjereniji pristup bilo unapređivanje $i$ reevaluacija postojećih mjera u skladu s teorijskim razvojem i empirijskim pokazateljima (Hox, 1997).

Glavni nedostatak zanemarivanja različitosti i teorijskih napredaka na tom području jest ugrožavanje konstruktne valjanosti. Najčešće, cilj je svakoga istraživačkog instrumenta što preciznije izmjeriti konstrukt i smanjiti pogrešku mjerenja. Zanemarivanjem različitih spolnih i rodnih identiteta ne ugrožavamo samo konstruktnu valjanost mjere nego i psihometrijsku karakteristiku osjetljivosti. Teorijski neutemeljenim sužavanjem raspona mogućih odgovora mjeru činimo manje osjetljivom i podložnijom pogrešci mjerenja, odnosno pogrešci klasifikacije sudionika/ 
ca (Glick i dr., 2018). Naposljetku, budući da se još uvijek mnoga istraživanja na području društvenih znanosti bave spolnim/rodnim razlikama (Tate, Ledbetter i Youssef, 2013) nužno je preispitati postojeće načine mjerenja kako bismo utvrdili radi li se o spolnim razlikama, rodnim razlikama ili nekoj nedefiniranoj kombinaciji tih mjera upitnih metrijskih karakteristika.

\section{KAKO POSTAVITI PITANJA O SEKSUALNIM I RODNIM IDENTITETIMA?}

Prije provedbe istraživanja važno je jasno odrediti ciljanu populaciju. Kvantitativna istraživanja na velikim uzorcima često obuhvaćaju osobe različitih seksualnih, spolnih i rodnih identiteta. $S$ druge strane, ovisno o cilju istraživanja, ponekad je bolje suziti uzorak jer osobe različitih identiteta mogu imati značajno različita iskustva. U takvim situacijama, skraćenicu koja se koristi u tekstu rada potrebno je prilagoditi obuhvaćenom uzorku. Na primjer, ako u istraživanju sudjeluju samo lezbijke i gejevi, za opis rezultata tog istraživanja nije prikladno koristiti akronim LGBTIQ ili LGBT.

\subsection{Seksualna orijentacija}

Pri istraživanju seksualne orijentacije mogu se koristiti kategorije različitih orijentacija (npr. homoseksualna, heteroseksualna, biseksualna, aseksualna, panseksualna, nešto drugo, ne želi se identificirati) ili kategorije seksualnih identiteta (npr. gej, lezbijka, biseksualna osoba, aseksualna osoba, panseksualna osoba, nešto drugo, ne želi se identificirati). Drugi pristup je korištenje mjera u obliku kontinuuma. $U$ tim mjerama privlačnost isključivo istom ili isključivo različitom spolu postavlja se na krajeve jednog kontinuuma (Kinsey, Pomeroy i Martin, 1948; kontinuum seksualnog ponašanja od sedam stupnjeva) ili se koriste odvojeni kontinuumi (Shively i DeCecco, 1977, prema Sell, 2007; zasebne procjene fizičke i emocionalne preferencije s dvije skale odgovora po čestici na pet stupnjeva, od u potpunosti nehomoseksualna do vrlo homoseksualna i od u potpunosti neheteroseksualna do vrlo heteroseksualna). Unutar mjera koje su usmjerene prema korištenju kontinuuma također postoje sveobuhvatne mjere poput Kleinove tablice seksualne orijentacije (Klein i dr., 1985, prema Štulhofer, 2004) koja osim privlačnosti, ponašanja i identiteta, obuhvaća i seksualne fantazije, emocionalne i društvene preferencije te životni stil. Kod te se mjere ističe i uključivanje vremenske komponente - od sudionika/ca se traže zasebne procjene svake od mjerenih dimenzija za prošlost (život do godinu dana prije istraživanja), sadašnjost (posljednjih godinu dana) i budućnost (što bi za osobu bilo idealno). Još jedna sveobuhvatna mjera je Upitnik 
o seksualnoj orijentaciji (Sell, 1996) koji na čak dvanaest čestica ispituje seksualnu privlačnost, seksualni kontakt te identitet temeljen na seksualnoj orijentaciji.

Nacionalni zdravstveni instituti (NIH), vrhovna agencija vlade SAD-a za biomedicinska i zdravstvena istraživanja, objavila je više preporuka za poboljšanje mjerenja seksualne orijentacije i rodnog identiteta u istraživanjima na tu temu (Federal Interagency Working Group on Improving Measurement of Sexual Orientation and Gender Identity in Federal Surveys, 2016a, 2016b). Rezultati njihovih pregleda istraživanja pokazuju da se najčešće koriste mjere različitih dimenzija seksualne orijentacije. Odabir prikladne mjere može ovisiti o karakteristikama populacije koju se istražuje. Na primjer, kod adolescenata/ica može biti prikladnije koristiti mjere seksualne i/ili romantične privlačnosti jer mladi možda još nemaju jasno definiran osjećaj identiteta u odnosu na vlastitu seksualnost. To je potvrđeno i u istraživanju o zdravlju adolescenata/ica u koje su uključena i pitanja o seksualnoj orijentaciji (Austin i dr., 2007). Naime, adolescentima/icama je najrazumljivija dimenzija seksualne orijentacije bila seksualna privlačnost u odnosu na seksualni identitet i seksualno ponašanje. Za istraživanja koja pak ispituju seksualno zdravlje prikladnije je mjeriti seksualno ponašanje kako bi se dobio podatak s kim sudionici/ce stupaju u seksualne odnose. Na opravdanost istodobnog ispitivanja različitih dimenzija seksualne orijentacije upućuju i rezultati istraživanja. Samoidentifikacija na različitim pitanjima o dimenzijama seksualne orijentacije ne mora se u potpunosti preklapati, nego može dolaziti do razlika između toga kako se osoba sama identificira, seksualne privlačnosti i seksualnog ponašanja. Na primjer, sve žene koje izjave da ih seksualno privlače žene ne moraju nužno imati i iskustvo seksualnog ponašanja koje uključuje žene niti se nužno samoidentificirati kao lezbijke (za pregled istraživanja vidjeti Sell, 2007).

Naposljetku, može se zaključiti da je čestice u istraživanju kojima će se ispitivati seksualna orijentacija potrebno oblikovati ovisno o cilju istraživanja (Sexual Minority Assessment Research Team, 2009). Ako seksualna orijentacija nije glavna tema istraživanja, nego se mjeri kao jedna od sociodemografskih karakteristika sudionika/ca, može se koristiti jedna čestica (za primjer usp. Tablicu 1). Za istraživanja koja detaljnije ispituju seksualnu orijentaciju, ili samo neku njezinu dimenziju, potrebno je koristiti više čestica. Također, ako želimo istražiti raširenost osoba koje izražavaju bilo kakvu tendenciju neheteroseksualnog ponašanja, privlačnosti i/ili identiteta, najbolje je ispitati sve dimenzije seksualne orijentacije.

\subsection{Spolni i rodni identitet}

Za mjerenje spolnog i rodnog identiteta može se koristiti tzv. "metoda dvaju pitanja”, odnosno primjena pitanja o spolu pripisanom pri rođenju koje slijedi pitanje o 
trenutačnom rodnom identitetu (Tate, Ledbetter i Youssef, 2013; Tablica 1). Osobe čiji se odgovori na ta dva pitanja podudaraju svrstavaju se u kategoriju cisrodnih osoba, a kod nepodudaranja zaključuje se da je riječ o transrodnim osobama. U slučaju da se na prvom pitanju osoba izjasni kao interspolna, autori/ce predlažu da ju se usmjeri na dodatno pitanje o tome u kojem rodu je odgajana. Valja primijetiti da ta metoda prepoznaje transrodnost kao krovni pojam za necisrodne identitete, ali ne prepoznaje transpolne osobe, odnosno one osobe koje žele prilagoditi ili su već prilagodile svoje primarne i/ili sekundarne spolne karakteristike medicinskim intervencijama.

Još jedna mogućnost je mjerenje "muževnosti" odnosno "ženstvenosti" na kontinuumu. Korištenje te mjere u istraživanju Magliozzi, Saperstein i Westbrook (2016) na dva američka nacionalna uzorka pokazalo je da se manje od četvrtine sudionika/ica poistovjećuje isključivo s jednom stranom kontinuuma, što je pokazatelj da te mjere možda bolje prikazuju rodnu raznolikost od uobičajenih kategorijalnih mjera. Ipak, one isključuju nebinarne rodne identitete poput genderqueer ili rodno neutralnih osoba.

Također, u istraživanjima se koristi i metoda jednog pitanja o rodu osobe u kojem se, uz uobičajene kategorije "muški" i "ženski", samo dodaju kategorije "transrodna osoba", "nešto drugo" i/ili druge kategorije koje označavaju trans identitete (Tate, Ledbetter i Youssef, 2013). Ta se metoda pokazala nepouzdanom jer ne omogućuje prikupljanje potpunih podataka: ne mogu se pouzdano identificirati cisrodne osobe niti se u dovoljnoj mjeri zahvaća raznolikost transidentiteta. No, važno je da se pokazalo, na uzorku adolescenata/ica, kako uvođenje opcije odgovora kojom se prepoznaju transrodne osobe za sudionike/ice nije bilo zbunjujuće. Točno su razlikovani transrodni od cisrodnih adolescenata/ica te uvođenje tih opcija nije utjecalo na odgovore cisrodnih osoba (Conron, Scout i Austin, 2008).

Rodno je izražavanje pak važno obilježje za istraživanja koja se odnose na nasilje i diskriminaciju LGBTIQ osoba. Naime, počinitelji nasilja često zapravo nemaju informaciju o seksualnoj orijentaciji ili spolnom/rodnom identitetu osobe, nego o žrtvi zaključuju temeljem njezina rodnog izražavanja.

Naposljetku, u bilo kojoj varijanti pitanja može se ostaviti prostor za samoodređenje, odnosno opcija "nešto drugo" s mogućnošću otvorenog odgovora. Preporuke o tim opcijama su različite, od toga da je važno dati mogućnost osobi da sama navede kako se identificira (Federal Interagency Working Group on Improving Measurement of Sexual Orientation and Gender Identity in Federal Surveys, 2016a), do toga da se to ne preporučuje jer je naknadna analiza dobivenih odgovora vremenski zahtjevna (Sexual Minority Assessment Research Team, 2009). Ipak, ostavljanje prostora za samoodređenje u pitanjima o spolnom/rodnom identitetu, kao i o seksualnoj orijentaciji, zapravo je jedini način da se prepoznaju i uvaže 
identiteti svih osoba koje sudjeluju u istraživanju, a uz veći broj ponuđenih kategorija smanjuje se brojnost opisnih odgovora i vremenska zahtjevnost daljnje analize.

Tablica 1. Primjeri čestica i pripadajućih odgovora za mjerenje seksualne orijentacije, spolnog i rodnog identiteta

\begin{tabular}{|c|c|c|c|}
\hline \multirow{2}{*}{$\begin{array}{l}\text { Konstrukt } \\
\text { spol }\end{array}$} & \multicolumn{3}{|c|}{ Primjeri čestica i pripadajućih odgovora } \\
\hline & \multirow{14}{*}{ 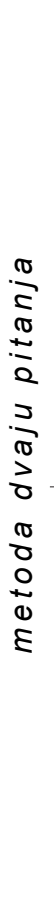 } & $\begin{array}{l}\text { Koji vam je biološki spol } \\
\text { dodijeljen pri rođenju? }\end{array}$ & $\begin{array}{l}\text { Koji odgovor najbolje opisuje vaš } \\
\text { spolni identitet? }\end{array}$ \\
\hline & & Ženski spol. & Ženski spol. \\
\hline & & Muški spol. & Muški spol. \\
\hline & & Interspolna osoba. & Transpolna osoba. \\
\hline & & Ostalo & Interspolna osoba. \\
\hline & & & Spolno se ne identificiram. \\
\hline & & & Ostalo \\
\hline \multirow[t]{7}{*}{ rod } & & \multicolumn{2}{|c|}{ Koji odgovor najbolje opisuje vaš rodni identitet? } \\
\hline & & \multicolumn{2}{|l|}{ Žena. } \\
\hline & & \multicolumn{2}{|l|}{ Muškarac. } \\
\hline & & \multicolumn{2}{|l|}{ Transrodna osoba. } \\
\hline & & \multicolumn{2}{|l|}{ Nebinarni rodni identitet. } \\
\hline & & \multicolumn{2}{|l|}{ Rodno se ne identificiram. } \\
\hline & & \multicolumn{2}{|l|}{ Ostalo } \\
\hline \multirow[t]{9}{*}{$\begin{array}{l}\text { seksualna } \\
\text { orijentacija }\end{array}$} & & $\begin{array}{l}\text { Koji odgovor najbolje opisuje } \\
\text { vašu seksualnu orijentaciju? }\end{array}$ & $\begin{array}{l}\text { Koji odgovor najbolje opisuje vaš } \\
\text { seksualni identitet? }\end{array}$ \\
\hline & & Aseksualna. & Aseksualna osoba. \\
\hline & & Biseksualna. & Biseksualna osoba. \\
\hline & & Heteroseksualna. & Heteroseksualna osoba. \\
\hline & & Homoseksualna. & Lezbijka. \\
\hline & & Panseksualna. & Gej. \\
\hline & & Ne identificiram se. & Panseksualna osoba. \\
\hline & & Ostalo & Ne identificiram se. \\
\hline & & & Ostalo \\
\hline
\end{tabular}




\section{ZAKLJUČAK}

Stjecanje znanja ciklički je proces. Vjerovanja o svijetu oblikuju nacrte istraživanja i načine prikupljanja podataka, a rezultati istraživanja pak oblikuju vjerovanja o svijetu, i tako u krug (Bowker i Leigh Star, 2000). Neovisno o tome bavi li se istraživanje eksplicitno LGBTIQ osobama ili ne, kod mjerenja sociodemografskih varijabli ne bi trebalo ignorirati njihovo postojanje. Pritom je važno da istraživači/ce poznaju odgovarajuću terminologiju te ne rabe zastarjele i pogrdne termine i tako perpetuiraju društvene stereotipe. Također, istraživanja bi trebala zahvaćati raznolikost obilježja neke skupine, a ne umjetno pojednostavljivati stvarnost na način kojim se gubi valjanost i objektivnost rezultata te bogatstvo postojećih razlika.

Istraživači/ce trebaju procijeniti, ovisno o temi istraživanja i obuhvaćenoj populaciji, hoće li rabiti mjere spola, roda i seksualne orijentacije te kako će oblikovati čestice. Na primjer, ako seksualna orijentacija i rodni identitet nisu relevantni za predmet istraživanja, a jedina je varijabla u kojoj bi moglo doći do isključivanja necisrodnih osoba varijabla spola, predlažemo dodavanje mogućnosti odgovora "ostalo" uz kategorije "muški" i "ženski". Ako se istraživanje bavi transrodnim osobama, svakako bi trebalo uključiti pitanja koja se odnose i na spolni i na rodni identitet osobe. Također, u situaciji kad se sudionicima/icama postavlja pitanje o partnerskim odnosima i roditeljstvu, dobro je postaviti i jedno pitanje o seksualnoj orijentaciji kako bi se prilikom analize podataka moglo procijeniti hoće li se provoditi samo na heteroseksualnim osobama u uzorku ili je moguće napraviti analizu i na neheteroseksualnim osobama u uzorku.

Dakle, uzimanje u obzir varijabli spolnog i rodnog identiteta te seksualne orijentacije ne mora značiti i značajno povećanje anketnog upitnika koje bi moglo utjecati na odaziv sudionika/ica u istraživanjima za koja se očekuje da će većinom obuhvatiti heteroseksualne i cisrodne osobe. U istraživanjima čiji su sudionici/ce LGBTIQ osobe, važno je uvrstiti pitanja o spolnom i rodnom identitetu te seksualnoj orijentaciji s više opcija odgovora kako bi se prepoznali i uzeli u obzir različiti identiteti. S tim u vezi, u različitim se istraživanjima može prilagoditi i terminologija. Manje zastupljene identitetske odrednice, poput primjerice aseksualne ili panseksualne orijentacije, mogu se koristiti u istraživanjima u kojima su LGBTIQ osobe ciljana populacija te su im ti termini poznati, dok u istraživanjima na općoj populaciji mogu biti obuhvaćeni ponuđenom opcijom odgovora "ostalo". Također, procijene li istraživači/ce da bi neki pojmovi sudionicima/ama mogli biti nejasni ili nepoznati, za njih mogu ponuditi objašnjenja.

U konačnici, na istraživačima/cama je odgovornost koliko će upoznati i razumjeti identitete LGBTIQ osoba i uvažiti njihova iskustva te izbjeći promatranje svijeta isključivo kroz heteronormativne naočale. 


\section{LITERATURA}

Američka psihološka asocijacija (1991). Avoiding Heterosexual Bias in Language, American Psychologist, 46 (9): 973-974.

Američka psihološka asocijacija (2006). Answers to Your Questions about Individuals with Intersex Conditions. Washington: American Psychological Association.

Američka psihološka asocijacija (2008). Answers to your questions: For a better understanding of sexual orientation and homosexuality. Washington: American Psychological Association.

Američka psihološka asocijacija (2015a). Guidelines for Psychological Practice with Transgender and Gender Nonconforming People, American Psychologist, 70 (9): 832 864. https://doi.org/10.1037/a0039906

Američka psihološka asocijacija (2015b). Key Terms and Concepts in Understanding Gender Diversity and Sexual Orientation among Students. Washington: American Psychological Association.

Austin SB, Conron JK, Patel A i Freedner N (2007). Making sense of sexual orientation measures: Findings from a cognitive processing study with adolescents on health survey questions, Journal of LGBT Health Research, 3 (1): 55-65. https://doi.org/10.1300/ J463v03n01_07

Batinica S (2010). Kirurška korekcija vanjskog spolovila u djevojčica sa sindromom kongenitalne adrenalne hiperplazije, Paediatria Croatica, 54 (1): 52-54.

Bowker GC i Leigh Star S (2000). Invisible mediators of action: Classification and the ubiquity of standards, Mind, Culture, and Activity, 7 (1-2): 147-163. https://doi.org/10.10 80/10749039.2000.9677652

Case P, Austin SB, Hunter DJ, Willett WC, Malspeis S, Manson JE i Spiegelman D (2006). Disclosure of sexual orientation and behavior in the Nurses' Health Study II: Results from a pilot study, Journal of Homosexuality, 51 (1): 13-31. https://doi.org/10.1300/ J082v51n01_02

Conron KJ, ScoutiAustin SB (2008). "Everyone Has a Right to, Like, Check Their Box:" Findings on a Measure of Gender Identity from a Cognitive Testing Study with Adolescents, Journal of LGBT Health Research, 4 (1): 1-9. https://doi.org/10.1080/15574090802412572

Državni zavod za statistiku (2011a). Popis stanovništva, kućanstava i stanova: 2. Stanovništvo prema narodnosti po gradovima/općinama. Zagreb: Državni zavod za statistiku.

Državni zavod za statistiku (2011b). Popis stanovništva, kućanstava i stanova: 6. Stanovništvo staro 15 i više godina prema vrsti zajednice u kojoj osoba živi, starosti $i$ spolu. Zagreb: Državni zavod za statistiku.

Durkalić M (2012). Queer teorija i Faucault. U: Spahić A i Gavrić S (ur.). Čitanka LGBT ljudskih prava, 2. dopunjeno izdanje. Sarajevo: Sarajevski otvoreni centar i Fondacija Heinrich Böll, 47-55.

Hrvatska zaklada za znanost (2018). Etički kodeks. Zagreb: Hrvatska zaklada za znanost.

European Union Agency for Fundamental Rights (2014). European Union lesbian, gay, bisexual and transgender survey: Main results. Luxembourg: Publications Office of the European Union.

European Union Agency for Fundamental Rights (2015). The fundamental rights situation of intersex people. Vienna: European Union Agency for Fundamental Rights. 
Factor R i Rothblum E (2008). Exploring gender identity and community among three groups of transgender individuals in the United States: MTFs, FTMs, and genderqueers, Health Sociology Review, 17 (3): 235-253. https://doi.org/10.5172/hesr.451.17.3.235

Federal Interagency Working Group on Improving Measurement of Sexual Orientation and Gender Identity in Federal Surveys (2016a). Evaluations of Sexual Orientation and Gender Identity Survey Measures: What Have We Learned? Washington: National Center for Education Statistics.

Federal Interagency Working Group on Improving Measurement of Sexual Orientation and Gender Identity in Federal Surveys (2016b). Toward a Research Agenda for Measuring Sexual Orientation and Gender Identity in Federal Surveys: Findings, Recommendations, and Next Steps. Washington: National Center for Education Statistics.

Gates GJ (2011). How many people are lesbian, gay, bisexual and transgender? Los Angeles: Williams Institute. https://escholarship.org/uc/item/09h684x2 (1. veljače 2019.)

Glick JL, Theall K, Andrinopoilos K i Kendall C (2018). For data's sake: Dilemmas in the measurement of gender minorities, Culture, Health \& Sexuality, 20 (12): 1-16. https:// doi.org/10.1080/13691058.2018.1437220

Hox JJ (1997). From theoretical concept to survey question. U: Lyberg L, Biemer P, Collins M, De Leeuw E, Dippo C, Schwarz N i Trewin D (ur.). Survey measurement and process quality. New Jersey: Wiley, 47-69. https://doi.org/10.1002/9781118490013.ch2

Hrvatska psihološka komora (2004). Kodeks etike psihološke djelatnosti. Zagreb: Hrvatska psihološka komora.

Huić A, Jelić M i Kamenov Ž (2015). Što predviđa spremnost heteroseksualnih osoba na pozitivno i negativno ponašanje prema osobama homoseksualne orijentacije?, Kriminologija i socijalna integracija, 23 (2): 79-109.

lantaffi A i Bockting WO (2011). Views from both sides of the bridge? Gender, sexual legitimacy, and transgender people's experiences of relationships, Culture, Health and Sexuality, 13 (3): 355-370. https://doi.org/10.1080/13691058.2010.537770

Kamenov Ž, Jelić M i Huić A (ur.) (2016). Problemi i izazovi seksualnih manjina u Hrvatskoj. Zagreb: FF Press.

Kinsey AC, Pomeroy WB i Martin CE (1948). Sexual Behavior in the Human Male. Philadelphia: W.B. Saunders.

Krosnick J i Presser S (2010). Question and questionnaire design. U: Marsden P i Wright J (ur.). Handbook of survey research. Bingley: Emerald Group, 263-315.

Magliozzi D, Saperstein A i Westbrook L (2016). Scaling Up: Representing Gender Diversity in Survey Research, Socius: Sociological Research for a Dynamic World, 2: 1-11. https://doi.org/10.1177/2378023116664352

Maragh-Bas AC, Torain M, Ranjit A, Shields RY, Snyder CF, German D, Schuur J i Haider AH (2017). Is it Okay to Ask: Transgender Patient Perspectives on Sexual Orientation and Gender Identity Collection in Healthcare, Academic Emergency Medicine, 24 (6): 655-667. https://doi.org/10.1111/acem.13182

Milas G (2009). Istraživačke metode u psihologiji i drugim društvenim znanostima. Zagreb: Naklada Slap.

Ministarstvo uprave (2016, 2017, 2018, 2019a, 2019b). Statistički prikaz Ministarstva uprave, br. 1, 5, 9, 13, 14. Zagreb: Ministarstvo uprave. https://uprava.gov.hr/statistickiprikaz/14431 (1. lipnja 2019.) 
Moser C (2016). Defining Sexual Orientation, Archives of Sexual Behavior, 45 (3): 505-508. https://doi.org/10.1007/s10508-015-0625-y

Nagoshi JL, Nagoshi CT i Bruzuzy S (2014). Feminist and Queer Theories: The Response to the Social Construction of Gender. U: Nagoshi JL, Nagoshi CT i Bruzuzy S (ur.). Gender and Sexual Identity: Transcending Feminist and Queer Theory. New York: Springer, 1529. https://doi.org/10.1007/978-1-4614-8966-5_2

Newport, F. (2018). In U.S., Estimate of LGBT Population Rises to 4.5\%. Gallup, 22 May. https://news.gallup.com/poll/234863/estimate-lgbt-population-rises. aspx?g_source=link_NEWSV9\&g_medium=TOPIC\&g_campaign=item_\&g_ content=In\%2520U.S.\%2c\%2520E stimate\%2520of\%2520LGBT-\%2520Population\%2 520Rises\%2520to\%25204.5\%2525 (1 February 2019)

Reja U, Lozar Manfreda K, Hlebec V i Vehovar V (2003). Open-ended vs. close-ended questions in web questionnaires, Developments in Applied Statistics, 19 (1): 159-177.

Schaeffer N i Dykema J (2011). Questions for surveys, Public Opinion Quarterly 75 (5): 909-961. https://doi.org/10.1093/poq/nfr048

Schilt K i Bratter J (2015). From multiracial to transgender? Assessing attitudes toward expanding gender options on the US Census, Transgender Studies Quarterly, 2 (1): 77-100. https://doi.org/10.1215/23289252-2848895

Sell RL (1996). The Sell assessment of sexual orientation: Background and scoring, Journal of Gay, Lesbian, and Bisexual Identity, 1 (4): 295-310.

Sell RL (2007). Defining and Measuring Sexual Orientation for Research. U: Meyer IH i Northridge ME (ur.). The Health of Sexual Minorities. Boston: Springer, 355-374. https:// doi.org/10.1007/978-0-387-31334-4_14

Sexual Minority Assessment Research Team (2009). Best Practices for Asking Questions about Sexual Orientation on Surveys. Los Angeles: Williams Institute. https:// williamsinstitute.law.ucla.edu/wp-content/uploads/SMART-FINAL-Nov-2009.pdf siječnja 2019.)

Simoni JM i Walters KL (2001). Heterosexual identity and heterosexism: Recognizing privilege to reduce prejudice, Journal of Homosexuality, 41 (1): 157-172. https://doi. org/10.1300/J082v41n01_06

Svjetska strukovna organizacija za zdravlje transrodnih osoba (2012). Standardi skrbi za zdravlje transpolnih, transrodnih i rodno nenormativnih osoba. Zagreb: Ženska soba.

Štulhofer A (2004). Uvod u razumijevanje seksualne orijentacije. U: Nikolić T (ur.). Kako se orijentišemo: Studija o seksualnoj orijentaciji. Beograd: Deve, 7-31.

Tate CC, Ledbetter JN i Youssef CP (2013). A Two-Question Method for Assessing Gender Categories in the Social and Medical Sciences, Journal of Sex Research, 50 (8): 767776. https://doi.org/10.1080/00224499.2012.690110

Transgender Europe (2017). Third gender marker options in Europe and beyond. Berlin: Transgender Europe. https://tgeu.org/third-gender-marker-options-in-europe-andbeyond/ (29. lipnja 2019.)

Westbrook L i Saperstein A (2015). New Categories are Not Enough: Rethinking the Measurement of Sex and Gender in Social Surveys, Gender \& Society, 29 (4): 534-560. https://doi.org/10.1177/0891243215584758 


\title{
How to Approach Measuring Sexual Orientation, Sex and Gender Identity? Recommendations for Research on Topics Related to LGBTIQ People
}

\author{
Marina MILKOVIĆ
}

Centre for Social Welfare Zagreb, Subsidiary Gornji grad - Medveščak, Zagreb, Croatia

marinamilkovic88@gmail.com

\author{
Marina ŠTAMBUK \\ Department of Management and Rural Entrepreneurship, Faculty of Agriculture, \\ University of Zagreb, Croatia \\ mstambuk@agr.hr
}

\section{ABSTRACT}

There has been an increasing interest in lesbian, gay, bisexual, transgender, intersex and queer (LGBTIQ) issues in social science research in Croatia. Additionally, LGBTIQ people can be sampled in almost any research. However, it is usually assumed that all study participants are heterosexual and cisgender. In consequence, a limited number of categories for LGBTIQ individuals are typically included in questionnaires. Such an approach results in biased sample characteristics, which can both affect the interpretation of results and provoke LGBTIQ participants to refrain from providing answers to certain questions or refuse further participation. In addition, it represents a violation of the scientific research ethical principle of avoiding discrimination or privilege based on sex, gender identity, and expression or sexual orientation. In this paper, recommendations are offered for research that acknowledges LGBTIQ people by including different response options for sexual orientation, sex, and gender identity. These recommendations are based on an overview of different theoretical explanations and approaches in the measurement of gender, sex and sexual orientation in Croatian and international research, as well as on the authors' experience in professional work with LGBTIQ people. As a possible step towards recognising LGBTIQ identities, introducing questions about sexual orientation and gender identity into research is recommended where those variables could be relevant for the studied subject. Also, since sex is a frequent research variable and commonly used response options "male" and "female" do not apply to a part of the population, adding a response option for self-identification or "something else" is recommended. In addition to item construction examples, explanations of the key concepts important for research including LGBTIQ people are provided.

Key words: sexual orientation, sex, gender, identity, measure, LGBTIQ people 